\title{
The results of experimental research of the parameters of methane capturing by local degassing wells in the undermining area
}

\author{
Kostiantyn Sofiiskyi ${ }^{1,}$, and Oleksandr Petukh ${ }^{1}$ \\ ${ }^{1}$ Institute of Geotechnical Mechanics named by N. Poljakov of National Academy of Sciences of \\ Ukraine, 49005, Dnipro, Simferopolska Str., 2a, Ukraine
}

\begin{abstract}
The article is devoted to the analysis of the results of the mine instrumental measurements of the local degassing system of the $m_{3}$ seam on the horizon of $1100 \mathrm{~m}$ of the mine named. V.M. Bazhanov to establish the basic rational parameters with the subsequent application of the biotechnological method of reducing the concentration of methane. As a result of mine instrumental measurements (vacuum-gas surveys at the borehole heads), the parameters of the degassing process (methane flow rate at the borehole heads and the average vacuum on them), technological parameters (angle of turn and tilt of wells, their length), well flow rate efficiency from the distance to the bottom of the longwall and the displacement of the undermined rocks. Establishing the basic parameters of degassing will allow you to quickly manage the flow rate of wells and underpressure at their mouths, taking into account the specific mining and geological and mining conditions. The use of biofilters allows controlling the concentration of methane in the atmosphere of mine roadway by methanotrophic bacteria.
\end{abstract}

\section{Introduction}

Currently, in the Donbas mines, the most widely used methods are the degassing of sites, based on methane captage through underground drainage wells drilled from development working. With the further deepening of mining, this method of degassing will not lose its prevalence due to its continuous improvement.

The concept of rational use of the subsoil provides for maximum extraction of energy from coal mines [1, 2]. Subsequent degassing of the plots should ensure safe mining conditions. This can be applied biotechnological methods of degassing [3], the effectiveness of which increases with the deepening of mining and the associated increase in temperature and methane concentration.

Like any technology, the degassing of underground wells has several disadvantages. Of them, the most significant are: relatively low productivity of methane due to low vacuum at borehole heads, long pipelines, significant air inflow into wells due to impaired leakage of their borehole head casing or part-time mining. Due to the influence of these and a number

\footnotetext{
*Corresponding author: igtmdep16@gmail.com
} 
of other factors, in the whole Donbass, from $28 \%$ to $45 \%$ of the volume of methane captured was utilized [4-6]. At most of the mines, methane is underpressured into the atmosphere as coal mining waste, and at a number of mines the degassing systems are operated extremely inefficiently, without ensuring the safety of mining operations. With increasing loads on the longwall, the requirements for the quality of methane capturing by local wells increase.

Uncertainty of the moments of connection, shutdown of wells and operational control of the capturing of methane leads to unjustified air leaks into the degassing system from the mined-out space and mine workings, reduces the efficiency of gas emission control at the site.

Previously known methods of dealing with air leakage [7] prevent them only in the borehole head. In the case of the presence of aerodynamic connection of wells with the mined-out space, it is almost impossible to eliminate the suction.

Thus, the study of the work of the local gas drainage system is relevant for improving the technological parameters of capturing coal mine methane, ensuring the safety of mining operations and improving the condition of the extracted gas mixture for its subsequent utilization. The scientific substantiation of the functioning parameters of the degassing system is possible only on the basis of an analysis of the causal relationship between the processes occurring in the extraction district.

The purpose of the mine experimental studies was to establish the main rational technological parameters of the operation of the local drainage system, represented by the workable wells and the pipeline.

\section{Methods}

Research methods - mine instrumental measurements (vacuum-gas surveys at the borehole head), mathematical processing of measurement results.

For the draining-out of gases of the site, the methane capture by wells drilled from a mine with an interval of $15 \mathrm{~m}$ in the over- and undermined rocks in the direction of the advance of the longwall was used. The angle of well turn to the mine is $35^{\circ}$, the angle of inclination is $30-44^{\circ}$, the average angle is $37^{\circ}$. The length of the wells is $70-90 \mathrm{~m}$, the average length is $71 \mathrm{~m}$.

Vacuum and gas surveys at the borehole head of the rising degassing wells were performed during 1 month of the site, at an average speed of longwall advance $2.5 \mathrm{~m} /$ day. On the date of the first observation, the removal of longwall from the face entry was about $700 \mathrm{~m}$, the next well closest to it was connected to the degassing pipeline $25 \mathrm{~m}$ from the longwall. Thus, the degassing system was dynamic: as the face run, new wells were put into operation and the lost methane production was turned off.

Surveying was performed according to the standard procedure [7]. Based on the measurements of the vacuum at the borehole heads, the pressure drop across the diaphragms and the concentration of methane in the mixture, the flow rate of methane from the wells was calculated.

\section{Results and discussion}

We carried out an analysis of the work of the precinct drainage system during the excavation of the $m_{3}$ reservoir by the 2nd eastern longwall mine. V.M. Bazhanova on the adit level $1100 \mathrm{~m}$. The layer is fulfilled by a solid system with a complete collapse of the roof. Reservoir output capacity is $1.60 \mathrm{~m}$. The longwall ventilation scheme is reciprocally accurate, with a cooling and underpressure of the outgoing jet through the ventilation mine 
roadway following the longwall. The mine roadway was guarded by gob pack of rock extracted during its conduct.

Analysis of the results of measurements of rarefaction at the borehole heads showed that the average rarefaction across the site was $3.7 \mathrm{kPa}(57 \%$ of the standard [8] value) with the minimum underpressure pressure at the site equal to $39 \%$ of the standard. The dependence of the underpressure at the borehole heads on the distance to the face of the longwall is shown in Figure 1. For all observations, a regular decrease in the underpressure in the direction from the face entry to the face of the longwall was observed, which is associated with the gas flow rate from the wells. After bringing the position of the borehole heads to a quasistatic state of the face of the longwall, we obtained a set of points reflecting the dependence of the vacuum $P$ on the borehole heads from the distance $l$ to the face of the longwall. Obviously, there is a fairly close relationship between the signs, which can be functionally approximated by an exponential dependence of the form:

$$
P=P_{0}+a \cdot m^{l}, \mathrm{~Pa},
$$

where $P_{0}-$ minimum underpressure in the degassing station, timed to the well closest to the longwall at the time of its connection to the system, $\mathrm{Pa} ; a, m$-empirical coefficients taking into account the technological parameters of degassing and mining and geological conditions of the reservoir development.

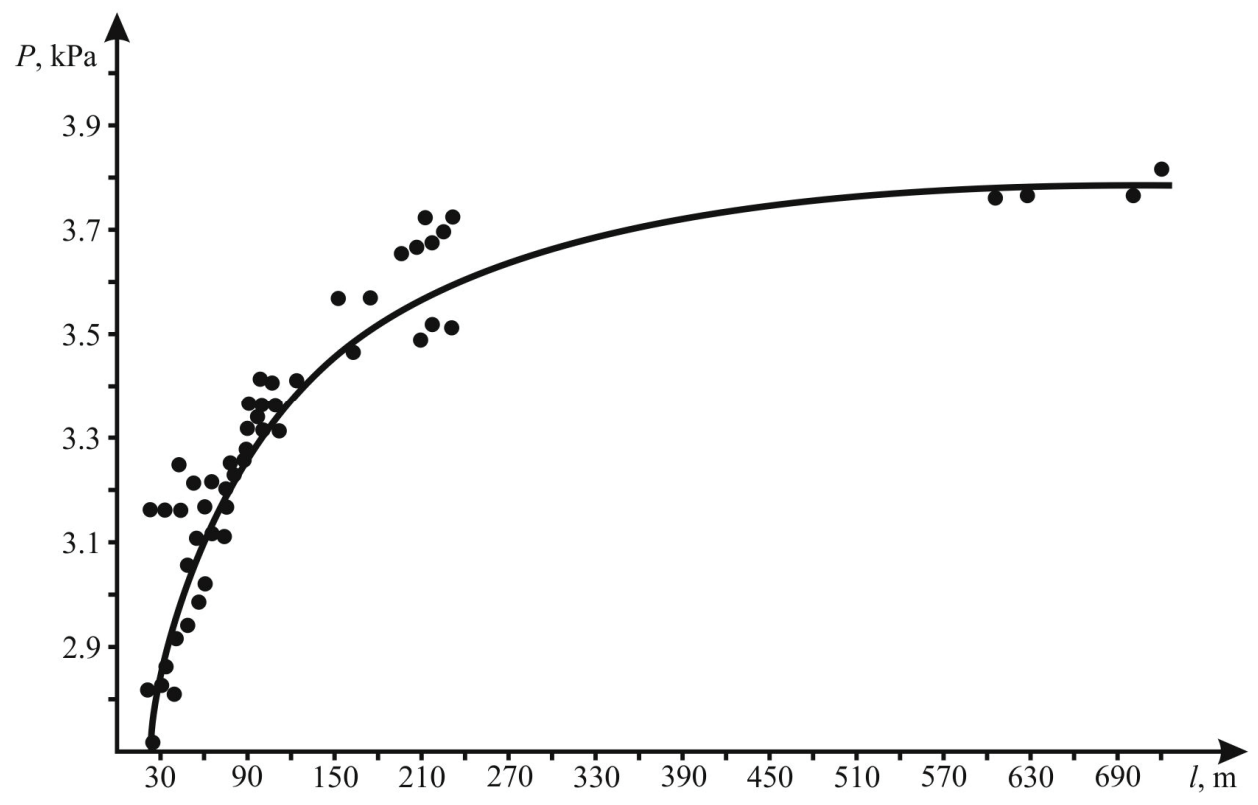

Fig.1. The dependence of the underpressure $P$ on the collar of the degassing wells on the distance to the longwall $l$.

Thus, with this development system and the degassing scheme of the plot, the dependence of the underpressure at the borehole heads is described by an exponential function. The underpressure at the borehole heads depends on their location relative to the face of the longwall, or, more precisely, on the position of their working part in the shift trough of undermine rocks. The closer the borehole head to the longwall, the less underpressure in it. This indicates that in addition to the influence of gas flow as the mixture moves to the boundary of the site, the productive part of each well is consistently 
located in the zones of the shift trough, for which the parameters of gas pressure, permeability and gas emission of rocks are different.

The absence of working wells at long intervals between wells allowed us to establish the parameters of air inflow into the local pipeline through the conduit joints. Under these conditions, the decrease in underpressure was $0.3 \mathrm{~Pa}$ per 1 running meter, or $4 \%$ for the whole site. With such an intensity of air inleakage, the total air flow into the stand at the joints averaged $0.51 \mathrm{~m}^{3} / \mathrm{min}$ and, with an average total methane consumption of $11.5 \mathrm{~m}^{3} / \mathrm{min}$, caused an additional decrease in its concentration by $4 \%$.

One of the parameters of the degassing system is the average for the site underpressure at the borehole heads (Fig. 2). At the first observation at 13 operating wells, the average underpressure was $3.85 \mathrm{kPa}$, at the second, at 14 wells $-3.81 \mathrm{kPa}$, at the third (11 wells) it decreased and amounted to $3.67 \mathrm{kPa}$, that is, with an increase and a subsequent decrease working wells rarefaction monotonously decreased. Further, with an increase in the number of active wells to 12, the underpressure sharply decreased. On the last observation, with 11 wells (as well as on the 3rd) the underpressure were almost equal.

This indicates that the number of simultaneously operating wells does not determine the average depression over the section at their collars.

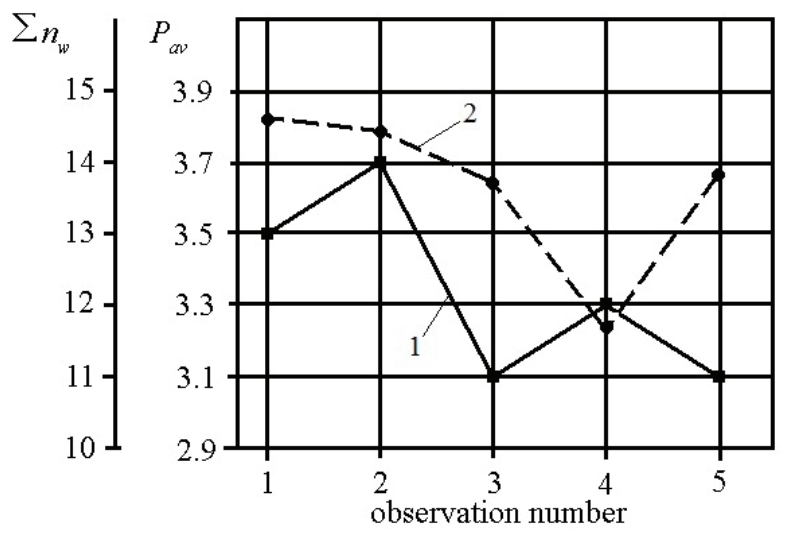

Fig. 2. The total number of operating degassing wells $\Sigma n_{w}(1)$ and the average underpressure in them $P_{a v}(2)$.

One of the main parameters of the functioning of the local drainage system is the flow rate of wells.

To estimate the distribution of methane production from wells, the bottom of the longwall was assumed quasi-static, and the data for all observations were shifted along the abscissa axis in accordance with the face advance. Air drift was divided into 10-meter intervals and determined the average flow rates of wells (Fig. 3).

An analysis of the experimental data showed that the dependence $Q_{C H 4}=f(l)$ is close to the normal distribution, where the extreme minimum of the well rate is confined to a distance of 150-200 m from the face of the longwall. The wells located on this interval do not make a significant contribution to the total flow rate; they dilute the captured mixture with air from the mine atmosphere, reducing the underpressure in the local gas pipeline. Five wells closest to the longwall, give $64 \%$ of the total flow rate of methane, two wells, located at more than 260 meters from the longwall - another $28 \%$. The remaining 4-7 wells operating at the site absorb only $8 \%$ of the total volume of methane, including the most distant from longwall - up to $4 \%$ each.

Therefore, from the point of view of the efficiency of capturing methane and extracting the conditioned mixture, operational control of the operation of wells should be applied at 
the site, for example, timely reducing the flow area of the borehole head with movable dampers-diaphragm or other methods. Under these conditions, it is necessary to operate the wells that are remote from the longwall to $100 \mathrm{~m}$, then partially differentiate their flow rate, and after the longwall recoil by $260 \mathrm{~m}$ and more, put them back into operation before the end of the excavation district.

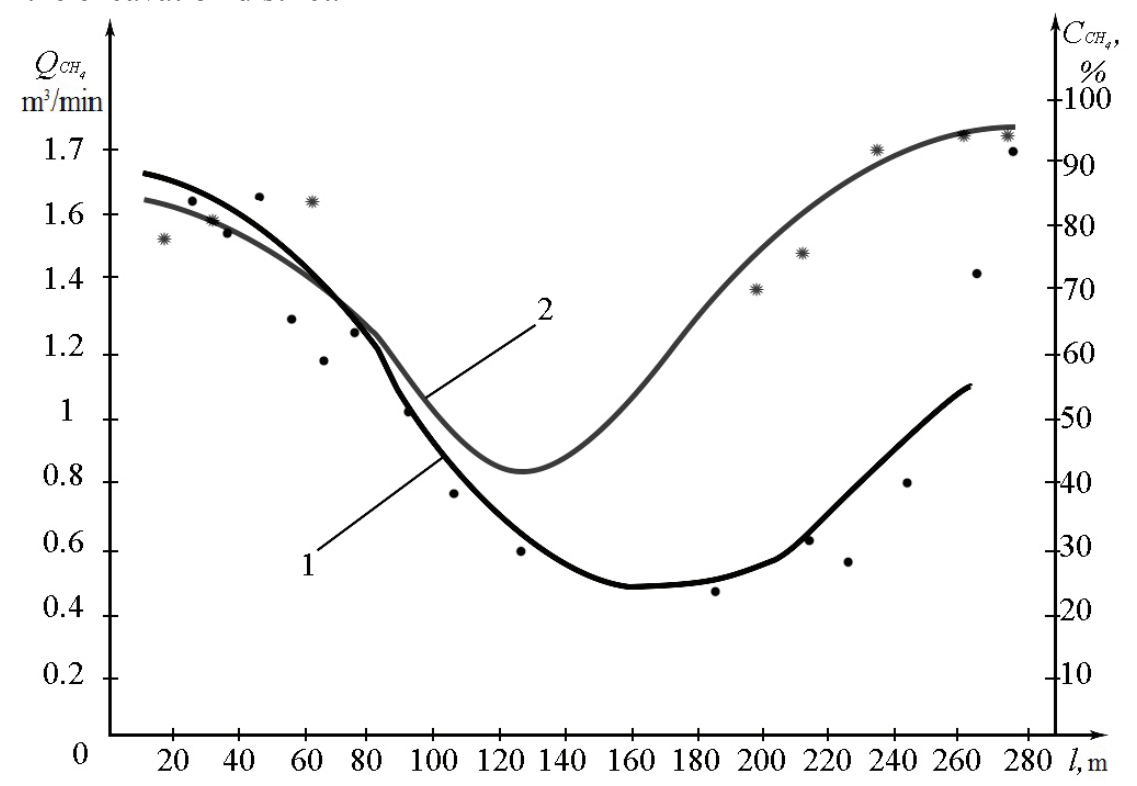

Fig. 3. Dependence of the flow rate of $Q_{\mathrm{CH} 4}$ of local degassing wells (1) and the concentration of methane $C_{C H 4}$ in the captured mixture (2) from the distance to the face of the longwall $l$.

A similar pattern can also be traced in the change in the concentration of methane in the capturing mixture (Fig. 3). In the wells closest to and farthest from the longwall, the concentration of methane is $80-95 \%$, and the minimum concentration (less than $50 \%$ ) is confined to the interval of $90-150 \mathrm{~m}$ from the longwall. Analysis of the results of observations showed that according to the criterion of condition of the captured mixture, it is necessary to reduce the productivity of wells, using the operational management of its flow rate.

Analysis of the topology of the degassing wells shows that when their borehole heads are located 90-150 m from the longwall, they are less effective in reducing gas emission, and the normal line, lowered from the working part of the wells to the formation plane, is $10-40 \mathrm{~m}$ from the longwall. In the same zone, as shown by the results of research, there is a maximum efficiency of the microbiological filter created in the mined-out space (methane concentration decreased by 3-4 times [3]), which makes it advisable to use methane captage and degassing the mined-out space using bacteria. In this case, the decrease in the efficiency of methane captage will be compensated by its oxidation by bacteria.

Let us further consider the connection of the parameters of methane captage with rock displacement under the conditions of a continuous system of development and degassing of the top covers by wells drilled in the direction of the advance of the longwall.

For dependences of the consumption of capturing methane and its concentration in the mixture with distance from the longwall, shown in Figure 3, similar patterns are observed.

Consequently, the close to normal distribution of methane production from wells with the removal from the face of the longwall is associated with the displacement and gas emission of undermine rocks of the top covers of been declining layer [9], the formation of technogenic methane collectors. At the time of connection to the degassing pipeline, the 
bottom of the well is located outside the zone of displacement of rocks, the borehole head is cased at a length of $4 \mathrm{~m}$ and is protected by a gob pack $15 \mathrm{~m}$ wide. The main part of the well crosses the zone of technogenic collectors filled with methane, which is under considerable pressure. Therefore, the wells closest to the longwall are the most productive and capture gas with a high concentration of methane, with a minimum within the site of underpressure on their borehole heads.

With the rejection of longwall, the well is in the stretching zone of the lower parts of the layers of the undermining top covers, the gob pack is compacted and an aerodynamic connection between the well and the undermining longwall space appears.

The presence of air leaks in the mined-out space, as well as the depletion of technogenic methane collectors occurring by that time, is accompanied by a decrease in the flow rate of the well and the occurrence of significant air inleakages, reducing the concentration of methane in the captured mixture.

With further longwall recoil, the well moves to the zone of interstitial closing and intersecting formation fractures, the gas permeability of rocks in the normal formation direction decreases. This leads to a decrease in air inleakages and an increase in vacuum in the well. In conjunction with a decrease in the intensity of air leaks in the mined-out space, these processes are accompanied by an increase in the flow rate of methane and an improvement in the condition of the captured mixture.

With the further movement of the half- trough of rock movement and the penetration of a well over the collapsed and compacted rocks of the immediate top covers, there is a slight residual flow rate of methane into the well from the mined-out space and long-existing cavities of stratification of rocks above its fixed boundary [10].

\section{Conclusions}

The displacement parameters of the undermined rocks determine the parameters of methane capturing. With this system of development and the method of degassing, there are regular changes in the flow rate of methane and its concentration in the captured mixture with distance from the longwall.

To optimize the parameters of the mixture being captured, it is necessary to quickly control the flow rate of wells and underpressure at their borehole heads, taking into account the displacement parameters in specific mining-geological and mining engineering conditions of the coal seam excavation. Methods of such control can be the installation of diaphragms at the borehole heads or downhole water ejectors.

The installation of biofilters at the borehole heads will allow not only to control the concentration of methane in the atmosphere of mining, but also to reduce it by 3-4 times using methanotrophic bacteria.

\section{References}

1. Puchkov, L.A., Slastunov, S.V., Kolikov, K.S. (2002). Izvlechenie metana iz ugolnyih plastov. Moskva: Moskovskiy gosudarstvennyiy gornyiy universitet

2. Bulat, A.F., Chemeris, I.F. (2006). Nauchno-tehnicheskie osnovyi sozdaniya shahtnyih kogeneratsionnyih energeticheskih kompleksov. Kyiv: Naukova dumka

3. Bulat, A.F., Sofiyskiy, K.K., Bokiy, B.V., Demchenko, V.B., Petukh, A.P., Zolotin, V.G (2014). Upravlenie kontsentratsiey metana $\mathrm{V}$ atmosfere gornyih vyirabotok metanotrofnyimi bakteriyami. Donetsk: Shidniy vidavnichiy dim

4. Chepenko, A.V. (2000). Karotazh i ispolzovanie shahtnogo metana v Ukraine, Geotekhnicheskaya mekhanika [Geo-technical mechanics], (17), 52-56 
5. Konarev, V.V., Seplyarskiy, D.G., Ryilov, V.F. (2000). Ob opyite razrabotki tehnologii degazatsii ugolnyih mestorozhdeniy v Donbasse, Geotekhnicheskaya mekhanika [Geotechnical mechanics], (17), 208-213

6. Filippov, A.E., Pisarenko, A.A., Triplett, D.R. (2002). Shahtnyiy metan v Ukraine: otsenka emissii i vozmozhnosti ispolzovaniya, Geotekhnicheskaya mekhanika [Geotechnical mechanics], (32), 14-22

7. Rukovodstvo po degazatsii ugolnyih shaht [Coal mine degassing guide] (1990). Moskva: Nedra

8. Perspektivyi dobyichi metana iz ugolnyih plastov v Velikobritanii (2002). [Prospects for the production of methane from coal seams in the UK], GeoDrill. Int., 10, (7), 1

9. Myakenkiy, V.I., Demchenko, V.B., Petuh, O.P., Kurdish, I.K. (2002). Sposib degazatsiyi viroblenogo prostoru lavi. Patent No 51440, Ukraine

10. Myakenkiy, V.I., Demchenko, V.B., Kalinichenko, A.P., Petuh, O.P., Shmigol, A.A., Kurdish, I.K. Gordienko, A.S., Kigel, N.F. (1991). Sposob degazatsii vyirabotannogo prostranstva lavyi. Patent No 1696739, USSR 